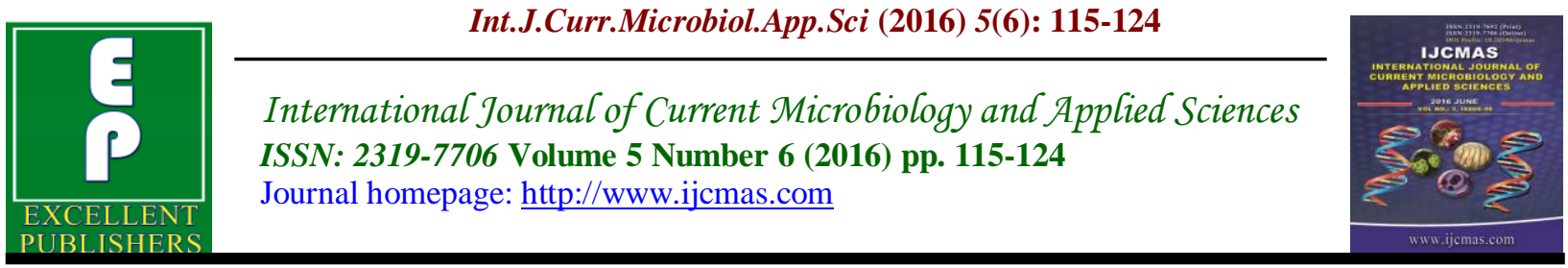

Original Research Article

http://dx.doi.org/10.20546/ijcmas.2016.506.014

\title{
Association and Variation of Endophytic Fungi among Some Macrolichens in Central Western Ghats, Southern India
}

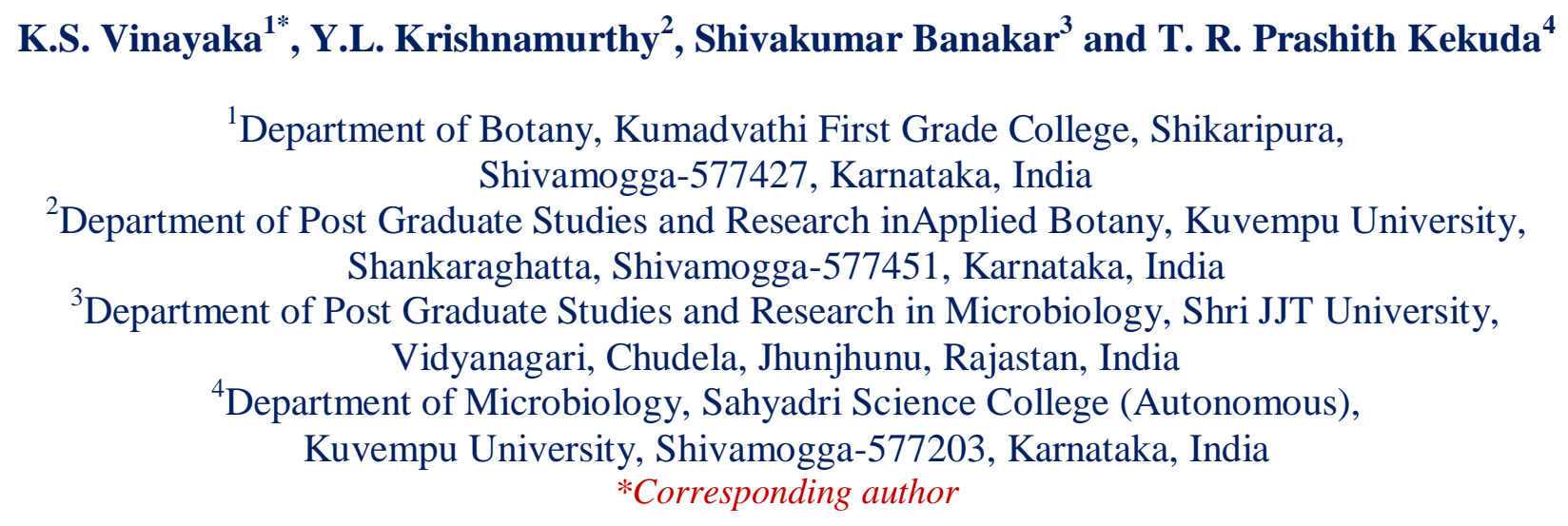

A B S T R A C T

\section{Keywords}

Macrolichens, Endolichenic fungi, Western Ghats, Chaetomium, Parmotrema.

Article Info

Accepted:

10 May 2016

Available Online:

10 June 2016
Association of endolichenic fungi with eleven lichen species belongs to five families distributed in Bhadra Wildlife Sanctuary, South India were investigated during May, 2013 to January, 2014. A total of 30 endolichenic taxa from 486 segments were isolated. The colonization rate ranged from $61.5 \%$ to $90.6 \%$ among lichen host species. Chaetomium globosum was occurred in eight, among 11 species of lichen, it was the dominant species of endolichenic fungi in thalli of lichens screened. The Ramalina pacifica and Parmotrema tinctorum showed maximum colonization by the endolichenic fungi. Out of 30 species of fungi 24 were sporulated and they were identified up to genus/species level. Chaetomium globosum, Fusarium spp., Xylaria sp. were isolated from thalli of 8, 5, 6 lichen species respectively. The Shannon index was 0.18-0.26 and Simpson species abundance was 0.004-0.015. Results of this study revealed that fungi were associated within lichen thalli other than symbiotic fungi and their compositions were varied with lichen species.

\section{Introduction}

Microbial endophytes have been found in the leaves, bark and xylem of higher plants (Schulz et al., 1993; Arnold and Lutzoni, 2007; Murali et al., 2007; Krishnamurthy et al., 2008) including grasses (White and Cole, 1985; Krishnamurthy and Hemalatha, 2003) also in lower forms like algae
(Hawksworth, 1988) and mosses (Dreyfuss, 1986). Endolichenic fungi also reported as parasymbionts in lichens (Petrini et al., 1990). A number of fungi grow and produce fruiting bodies on the surface of lichen thalli with identical fructifications. The hyphae of these fungi penetrate the lichen thalli and 
form intimate union with cells of the algal symbiont (Ahmadjian, 1967). There are about 300 genera and 1000 species of obligatory lichenicolous fungi known which form parasitic, saprophytic, parasymbiotic and obligatory symbiotic mode of biological relationships on lichen species. Endolichenic fungi are fungi that live within their host plants causing any noticeable symptoms of disease (Hawksworth and Hill, 1984). These are distinct from lichen mycobionts or any other previously recognized fungal associates of lichens. They represent the same major lineages of Ascomycota as do fungal endophytes, largely parallel the high diversity of endophytes from the arctic to the tropics (Arnold et al., 2009). For about 32 taxa of endophytic fungi with 14 ascomycetes, 16 hypomycetes, each of coelomycete and yeast were reported (WenChao et al., 2007). Scopyleriopsis was distributed in all 6 species of macrolichens. About 70 cultures of black fungi belong to Chaetothriomycetidae and Dothideomycetidae from 14 different species of lichen thalli, they showed that some lineages of black fungi can opportunistically grow on lichens (Harutyunyan et al., 2008). A recovery of endolichenic fungi from tissue segments of lichen thalli showed that these fungi not found on surface sterilized lichen thalli (Arnold et al., 2009). The colonization of fungi was considered environmental contaminants (Frankland, 1974). Fungi belong to soil and litter symbiosis or pathogenic also isolated from fruticose lichens which were symbionts or pathogens of higher plants and lichens inhabiting fungi (Petrini et al., 1990). Although there are several studies on endophytic microorganisms of higher plants, very few studies were carried out on the isolation of endolichenic fungi from the lichen thallus in India (Suryanarayanan et al., 2005). Therefore, we have examined some lichen species for isolation of endolichenic fungi from the internal tissues of macrolichens which commonly occur in forests of Bhadra Wildlife Sanctuary, Southern India.

\section{Materials and Methods}

\section{Sampling of Lichens}

A total of eleven lichen specimens were collected from different habitats of Bhadra wildlife sanctuary, $\left(75^{\circ} 15^{\prime}\right.$ and $75^{\circ} 50^{\prime} \mathrm{E}$ to $13^{\circ} 25^{\prime}$ and $\left.13^{\circ} 50^{\prime} \mathrm{N}\right)$ Karnataka, Southern India (Table 1). Apparently healthy looking lichen thalli were brought to the laboratory, in paper bags stored in refrigerator and processed within 24 hours. The lichen specimens were identified by using the manual (Awasthi, 1988). These lichen samples are stored in the herbarium of Department of Applied Botany, Kuvempu University, Karnataka, India.

\section{Isolation of Endolichenic Fungi from Lichen Thalli}

Surface sterilization of lichen thalli was performed using the modified method (Guo et al., 2003). Healthy looking thalli of each lichen specimens were cleaned in tap water to remove dirt and then thoroughly washed under running tap water. These lichen thalli were surface sterilized by consecutive immersion for one minute in $75 \%$ ethanol, 3 minute in $2 \%$ Sodium hypochlorite and 3 seconds in $75 \%$ ethanol and washed several times with sterile distilled water. The thalli were surface dried with sterile paper and cut into $1 \mathrm{~cm}$ sized lichen segments and then plated on nutrient medium consisted of $2 \%$ malt extract, 0.4 yeast extract and $2 \%$ agar to which $50 \mathrm{mg} / 1$ chlortetracyline used as antibacterial antibiotic (Petrini et al., 1990). The plates were incubated at $25^{\circ} \mathrm{C} \pm 2$ for 10 15 days under Philips fluorescent tube light for $12 / 12 \mathrm{~h}$ day and night alternate light conditions. They were examined regularly 
and colonies developed were transferred immediately to new petri dishes with PDA medium for identification. Sterilized tissue segments were pressed down on to the surface of PDA medium to check back the efficacy of surface sterilization procedure and to confirm endolichenic isolations only from internal tissues of lichen segments. Absence of growth of any fungi on the medium confirmed that surface sterilization procedure was effective in removing the surface fungi as reported in a previous study (Schulz et al., 1993). Morphology of subcultures on PDA were examined periodically and identified when isolates were sporulated (Domsch and Gams, 1972; Nagamani et al., 2006 ). The fungal cultures that failed sporulation even after two months of incubation were named as mycelia sterilia (Schulz et al., 1993). Pattern of fungal association with lichens on nutrient rich and poor media was also done in order to understand influence of different medium on fungal growth. The surface sterilized lichen segments were incubated on 3 such media viz., PDA (Dextrose-20g, Agar- 15g, potato 200g/ $1000 \mathrm{ml} \mathrm{pH}-5.6 \pm 0.2$ ), MYA (Malt extract- $10 \mathrm{~g}$, Yeast extract- $4 \mathrm{~g}$, Glucose- $4 \mathrm{~g}$ and Agar 5g pH-7.5 \pm 0.2 ) and CZA (Sucrose-30g, $\mathrm{NaNO}_{3}-3 \mathrm{~g}, \mathrm{~K}_{2} \mathrm{HPO}_{4}-1 \mathrm{~g}$, KCl0.5g, $\quad \mathrm{MgSO}_{4} .7 \mathrm{H}_{2} \mathrm{O}-0.01 \mathrm{~g}, \quad$ Agar- $15 \mathrm{~g}$, distilled water $1000 \mathrm{ml}, \mathrm{pH} \quad 6.2 \pm 0.3)$. Incubation conditions maintained were as mentioned earlier.

\section{Data Analysis}

The Relative Frequency (RF \%) of occurrence of endolichenic fungi was calculated as the total number of taxon divided by the total number of taxa obtained from lichen thalli incubated (Arnold et al., 2009). The Shannon-Weiner diversity index $\left(\mathrm{H}^{\prime}\right)$ was calculated according to the formula $\mathrm{H}^{\prime}=\sum$ pi $\mathrm{x}$ lnpi to asses species richness and Simpson diversity index (D') was calculated according to the formula $\mathrm{D}^{\prime}=1 / \sum$ (pi) ${ }^{2}$, where $k$ is the total number of fungal species and $p i$ is the proportion of individual that species $i$ contributes to the total (Pielou, 1975). Simpson index was calculated to understand species diversity of endolichenic fungi occurred in lichen thalli.

\section{Results and Discussion}

A total of 30 different endolichenic fungal species were recovered from 11 species of foliose and fruticose lichens (Table 2). Twenty four species of fungi have produced fructifications in culture and have been identified to genus or species level and rest were categorized as sterile forms (Table 3 ). The high colonization rate $(61.5-90.6 \%)$ of endolichenic fungi was observed among eleven lichen species in this study. Maximum colonization rate was observed in Parmotrema cristiferum $(90.6 \%)$ and $P$. reticulatum $(90.3 \%)$ and moderate in Cladonia fruticulosa (61.5\%). Among the 30 isolates, 24 species were identified in that most of them were belonging to ascomycota and all other isolates categorized as Mycelia sterilia (6). A moderate to high per cent of endolichenic fungi occurred in this study from eleven species of macrolichens. After a thorough surface sterilization protocol, and incubation, all the fungi expressed from the cut ends of the thalli. This is confirmed as sterilized thalli were pressed on to the medium to check back the possibility of contaminants on the surface of thallus to know effectiveness of surface sterilization.

The fungal species associated with thalli of lichen species such as Chaetomium globosum (8 species of lichens), Cladosporium cladosporioides (5), Colletotrichum dematium (5), Fusarium heterosporum (4), Phoma sp. (3) and Xylaria (6). C. globosum species showed high rate of relative frequency in the lichen 
host where as Parmotrema sp. as evidenced by maximum number of isolates of endolichenic fungi (12.82\%). Endolichenic fungi grew on different nutrient rich and poor media showed that there is no much variation in the appearance of colonies as well as density of sporulation or occurrence of some different strains. However MYA influenced expression of more number of colonies (77) than PDA (69) and CZA (65). Per cent occurrence varied from 0.5 to 50 on all three media (Table 4). Shannon diversity index showed higher value in Parmotrema reticulatum (0.26) and lower in Parmotrema tinctorum (0.18). Simpson's index also showed species abundance higher in Parmotrema reticulatum (Figure1). It is a fact that lichen species such as $P$. reticulatum and $P$. tinctorum harbored about $90 \%$ of endolichenic fungi. This data was based on number of segments encountered with these fungi against total number of segments incubated.

The terms lichenicolous or endolichenic fungi are different because of their occurrence or association on surface or within tissues of internal parts. Some researchers claim the term endolichenic because they isolated from internal tissues (Petrini et al., 1990; Suryanarayanan et al., 2005) and others isolated endolichenic fungal strains that lived along in the lichen thallus Pseudocephaelaria sp. Usnea sp. and Parmotrema sp. (Kannangara et al., 2009). The associations of fungi other than their obligate mycobiont also existed. Experimental evidence demonstrates that these endolichenic fungi distinctly different from lichenicolous fungi (Suryanarayanan et al., 2005; Girlanda et al., 1997; U'Ren et al., 2009). Lichenicolous fungi are lichen forming fungi which are one of the important components of symbiosis (Hawksworth and Hill, 1984). Some of the fungi isolated in this study from lichen host may also represent lichenicolous fungi. The
Shannon index is employed to evaluate and compare the diversity of fungal community between different lichen species. One of the researcher, he reported that the ShannonWeiner diversity index was 0.48-1.85 (WenChao et al., 2007). In the present study, the results had showed the higher diversity between the lichen species.

In a study, isolation of about 506 species of endolichenic fungal species from 17 lichen species was carried out and it was illustrated that some fungi were surface colonizers and rests were true endophytes (Petrini et al., 1990). The colonization rate of endolichenic fungi from lichens such as Parmelia taractica $(90 \%)$ and Peltigera praetextata (70\%) was reported (Girlanda et al., 1997). Several authors have suggested that lichenicolous or parasymbiotic fungi are especially diverse in tropical forests (Frohlich and Hyde, 1999; Arnold et al., 2000). One of the researcher, he recovered 24 endolichenic fungi from five corticolous lichens such as Dirinaria picta, Heterodermia diademata, Physcia aipolia, Pyxine cocoes and Roccella montagnei and he concluded that these fungi are not contaminants (Suryanarayanan et al., 2005). Endolichenic fungi have an intimate association and live in the thalli of lichens that are analogous to plant endophytic fungi (Arnold and Lutzoni, 2007). In a recent study on lichen thalli through surface sterilization, the endolichenic fungi occurred within tissues rather than upon lichen thalli. Scanning electron microscopy results of six lichen thalli made no evidence of extra spores within the lichen thalli. The anatomical studies confirmed that endolichenic fungi associated with green algal photobiont layer (Arnold et al., 2009).

The investigation of this study revealed that association of $C$. globosum, $C$. cladosporioides, C. dematium, Fusarium spp., Phoma sp. and Xylaria sp., are other 
than lichenicolous fungi with lichen thalli collected from forests. These endolichenic fungi may assist in lichen thallus formation and growth also act as antagonistically against insect herbivores. Some endophytic microorganisms were characterized known to produce secondary metabolites are of valuable pharmaceutical substance which are having biotechnological and industrial interest (Culberson, 1969; Strobel and Long, 1996). Results of several studies demonstrated that lichen associated fungi are a good resource for new bioactive natural products.

Table.1 Lichens studied for isolation of endolichenic fungi

\begin{tabular}{|l|c|c|c|}
\hline \multicolumn{1}{|c|}{ Lichens } & Family & Form & Habitat \\
\hline Cladonia fruticulosa Kremp. & Cladoniaceae & Fruticose & Terricolous \\
\hline Heterodermia dendritica (Pers.) Poelt. & Physciaceae & Foliose & Corticolous \\
\hline H. incana (Stirton) D.D.Awasthi & Physciaceae & Foliose & Corticolous \\
\hline Parmotrema reticulatum (Taylor) Choisy & Parmeliaceae & Foliose & Saxicolous \\
\hline P. tinctorum (Despr.ex Nyl.) Hale & Parmeliaceae & Foliose & Corticolous \\
\hline P. cristiferum (Taylor) Hale & Parmeliaceae & Foliose & Corticolous \\
\hline Ramalina arabum (Ach.) Meyen \& Flot. & Ramalinaceae & Fruticose & Corticolous \\
\hline R. pacifica Asahina & Ramalinaceae & Fruticose & Corticolous \\
\hline Teloschistes flavicans (Sw.) Norm. & Teloschistaceae & Fruticose & Corticolous \\
\hline Usnea stigmatoides G. Awasthi & Parmeliaceae & Fruticose & Corticolous \\
\hline U. galbinifera Asahina & Parmeliaceae & Fruticose & Corticolous \\
\hline
\end{tabular}

Table.2 Colonization of endolichenic fungi in eleven species of lichens

\begin{tabular}{|l|c|c|c|}
\hline \multicolumn{1}{|c|}{ Lichen species } & $\begin{array}{c}\text { No. of } \\
\text { tissue } \\
\text { segments }\end{array}$ & $\begin{array}{c}\text { No. of } \\
\text { isolates }\end{array}$ & $\begin{array}{c}\text { Colonization } \\
\text { rate (\%) }\end{array}$ \\
\hline Cladonia fruticulosa & 13 & 8 & 61.5 \\
\hline Heterodermia dendritica & 20 & 16 & 80.0 \\
\hline H. incana & 26 & 21 & 80.8 \\
\hline Parmotrema reticulatum & 31 & 28 & 90.3 \\
\hline P. tinctorum & 120 & 90 & 75.0 \\
\hline P. cristiferum & 64 & 58 & 90.6 \\
\hline Ramalina arabum & 46 & 41 & 89.1 \\
\hline R. pacifica & 98 & 83 & 84.7 \\
\hline Teloschistes flavicans & 11 & 8 & 72.7 \\
\hline Usnea stigmatoides & 29 & 20 & 68.9 \\
\hline U. galbinifera & 36 & 28 & 77.7 \\
\hline Total & 486 & 409 & \\
\hline
\end{tabular}


Table.3 RF (\%) of endolichenic fungi isolated from lichen species

\begin{tabular}{|c|c|c|c|c|c|c|c|c|c|c|c|c|}
\hline $\begin{array}{l}\text { Sl. } \\
\text { No. }\end{array}$ & Fungal species & $\mathrm{Cl}$ & Hd & $\mathrm{Hi}$ & $\operatorname{Pr}$ & $\mathbf{P t}$ & Pc & $\mathbf{R a}$ & $\mathbf{R p}$ & Tf & Us & Ug \\
\hline 1 & $\begin{array}{l}\text { Alternaria alternata (Fr.) } \\
\text { Keissler }\end{array}$ & 2.6 & & & 12 & 10.6 & & & & & & \\
\hline 2 & Aspergillus niger Van. Tieghem & & & & & & 9.3 & 7.6 & & 3.6 & & 14.5 \\
\hline 3 & $\begin{array}{l}\text { Chatomium globosum Kunze } \\
\& \text { Schm }\end{array}$ & 4.0 & 1.8 & & 8 & 6.4 & 3.2 & & 12.2 & 2.2 & 6 & \\
\hline 4 & C. elatum Kuze & & & & 10 & & & 7.6 & & & & 5.8 \\
\hline 5 & Chaetomium sp. & & & 5 & 30 & 16 & 14 & 11.5 & 9.8 & & & \\
\hline 6 & $\begin{array}{l}\text { Colletotrichum dematium (Fr.) } \\
\text { Grove }\end{array}$ & & 4.3 & & & 3.5 & & 4.6 & 8.1 & & 6 & \\
\hline 7 & $\begin{array}{l}\text { Cladosporium cladosporioides } \\
\text { (Fres.) de vries. }\end{array}$ & & & 6.6 & & & & 11.5 & & 11 & 18 & 9.6 \\
\hline 8 & Chalara sp. & & & & 9.2 & & & 7.6 & & & 18 & \\
\hline 9 & $\begin{array}{l}\text { Curvularia lunata (Wakker) } \\
\text { Boedijn }\end{array}$ & & 5.2 & & & & & & 12.2 & & 12 & \\
\hline 10 & $\begin{array}{l}\text { Fusarium heterosporum Nees } \\
\text { ex Fr. }\end{array}$ & 2.6 & & & & & 5.6 & & 7.5 & & & 5.8 \\
\hline 11 & F. lateritium Nees ex Fries & & 13 & 10 & & & & 11.5 & & 11 & 12 & \\
\hline 12 & F. solani (Mart.) Sacc. & & & & 20 & & 14 & & 4.4 & & 9 & \\
\hline 13 & Hypoxylon sp. & 8 & & & 10 & & & & & & & \\
\hline 14 & Phoma sp. & & & 10 & & 9.1 & & & & 2.2 & & \\
\hline 15 & P. leveillei Boerema \& Bollen & 8 & 6.5 & & 20 & & & 9.2 & & & & \\
\hline 16 & Phialophora verrucosa Medlar. & & & 10 & & & & & 6.1 & & & 2.4 \\
\hline 17 & $\begin{array}{l}\text { Penicillium chrysogenum } \\
\text { Thom. }\end{array}$ & & 8.6 & & 15 & & & & & & 9 & \\
\hline 18 & $\begin{array}{l}\text { Pestalotiopsis hypodermia } \\
\text { (Niessl) Steyaert }\end{array}$ & & & & 5.2 & 3.2 & & & & 1.2 & & \\
\hline 19 & Rhizoctonia solani Kuhn. & & & 2.8 & & & 9.3 & & & & 7.2 & \\
\hline 20 & $\begin{array}{l}\text { Trichoderma viride Per. ex } \\
\text { Fries }\end{array}$ & 1.6 & & & & 7.1 & & 15.3 & & & 7.2 & \\
\hline 21 & Thielavia sp. & & 6.5 & 6.6 & & & & & & & & \\
\hline 22 & T.basicola (Berk. \& Br.) Zopf. & & & & 15 & & & 6.5 & & & & 5.8 \\
\hline 23 & Xylaria sp. & 2.0 & & & 12 & & 4.6 & 7.6 & & 5.5 & & 2.0 \\
\hline 24 & X. vaporaria Berk. & & & & 17.1 & & 7 & 15.3 & 8.1 & & & \\
\hline 25 & Mycelium Sterile- 1 & & 8.6 & 4 & & 6.4 & & 15.3 & & & & 3.6 \\
\hline 26 & Mycelium Sterile -2 & 2.6 & & & 17.1 & & & & 7 & & & \\
\hline 27 & Mycelium Sterile -3 & & 8.6 & & & & & & & 3.6 & 5.1 & \\
\hline 28 & Mycelium Sterile -4 & & 5.2 & 5 & & & & & & 1.8 & 2.7 & \\
\hline 29 & Mycelium Sterile -5 & 2.6 & & 6.6 & & & & & 6.5 & & & \\
\hline 30 & Mycelium Sterile -6 & & 13 & & 24 & & 7 & & 4.4 & 2.2 & & 7.2 \\
\hline
\end{tabular}

(Cl- C.fruticulosa, Hd- H.dendritica, Hi- H.incana, Pr- P.reticulatum, Pt- P.tinctorum, Pc- P.cristiferum, Ra- R.arabum, Rp- R.pacifica, Tf- T.flavicans, Us- U.stigmatoides, Ug- U.galbinifera) 
Table.4 Influence of different nutrient media on pattern of endolichenic fungal isolation

\begin{tabular}{|l|c|c|c|}
\hline a) Fungal species & MYA (\%) & PDA (\%) & CZA (\%) \\
\hline Alternaria alternate & 2.0 & 1.0 & 1.0 \\
\hline Aspergillus niger & 2.5 & 2.5 & 1.0 \\
\hline Chaetomium globosum & 0.5 & 1.0 & - \\
\hline Colletotrichum dematium & - & 1.0 & - \\
\hline Cladosporium cladosporioides & 12.5 & 1.0 & 1.0 \\
\hline Curvularia lunata & - & 1.0 & - \\
\hline Fusarium heterosporum & 0.5 & - & 0.5 \\
\hline Hypoxylon sp. & - & - & 0.25 \\
\hline Penicillium chrysogenum & 50.0 & 50.0 & 37.5 \\
\hline Penicillium sp. & - & 0.5 & 0.75 \\
\hline Pestalotiopsis hypodermia & 30.0 & 30.0 & 25.0 \\
\hline Trichoderma viride & 42.5 & 35.0 & 32.5 \\
\hline Xylaria sp. & - & 2.0 & - \\
\hline Mycelium Sterile- 1 & 0.50 & - & - \\
\hline Mycelium Sterile -2 & 0.75 & 0.25 & 1.0 \\
\hline Mycelium Sterile -3 & 1.0 & - & \\
\hline Mycelium Sterile -4 & 0.75 & 0.5 & 2.0 \\
\hline Mycelium Sterile -5 & - & 1.0 & 2.0 \\
\hline Mycelium Sterile -6 & - & 2.0 & - \\
\hline b) Total isolates & $\mathbf{7 7}$ & $\mathbf{6 9}$ & $\mathbf{6 5}$ \\
\hline
\end{tabular}

MYA- Malt Yeast extract Agar, PDA- Potato Dextrose Agar, CZA- Czapek Dox Agar

Fig.1 Shannon and Simpson diversity index studied in eleven species of lichens

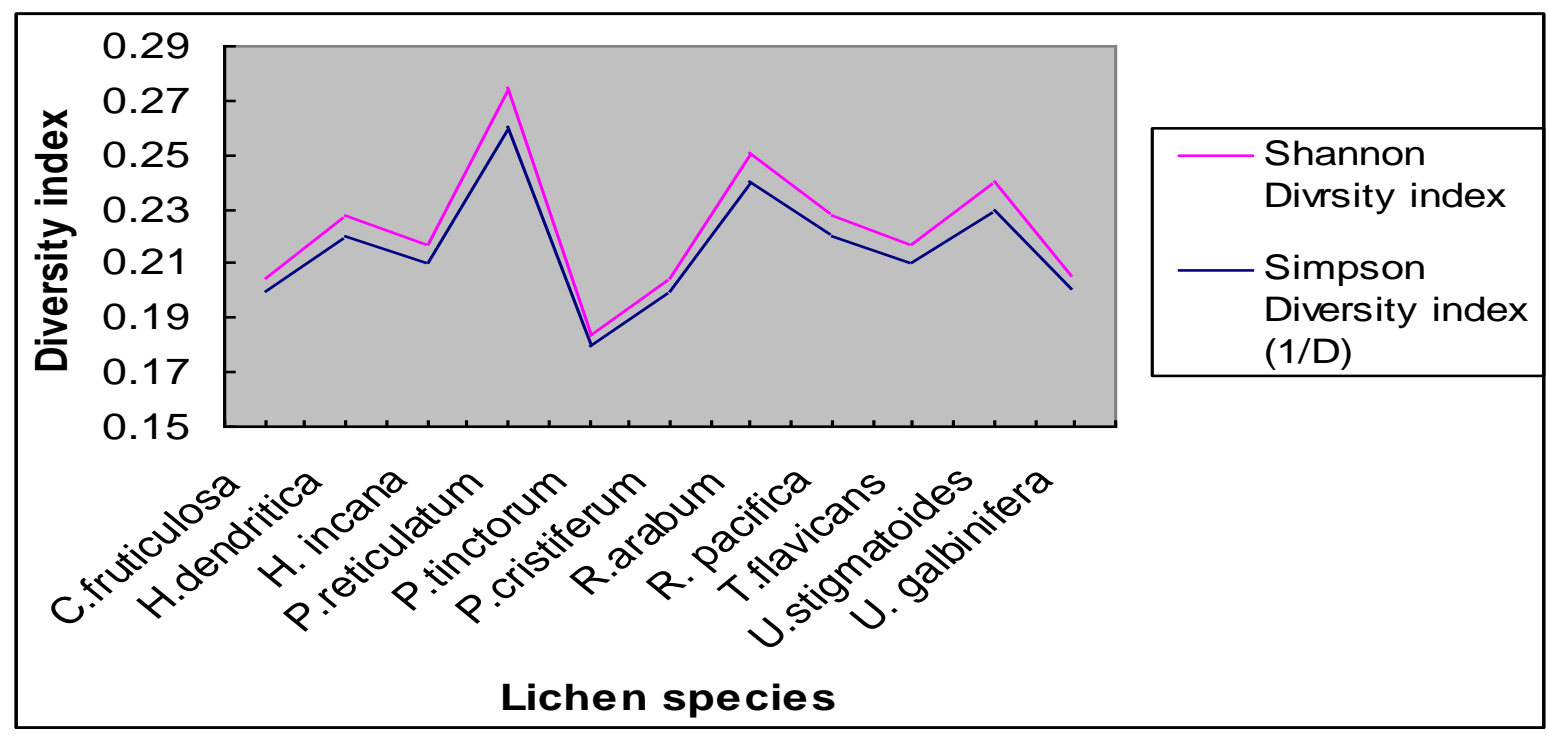

The endolichenic fungi like Pestalotiopsis sp. known to produce antifungal metabolites such as ambuic acid and torreyanic acid from lichen Clavaroids sp. (Ding et al., 
2009). Endolichenic fungal strains isolated from lichen thalli Pseudocephellaria sp., Parmotrema sp. and Usnea sp. showed antifungal activities against common plant pathogenic fungi. They were also capable of utilizing the substrates by producing specific enzymes (Pielou, 1975). An unidentified lichenicolous strain LL-RB 0668 yielded lichenicolous A and B which are Bisnapthopyrones (He et al., 2005). An endolichenic fungus Neurospora terricola produce allenyl phenyl ethers and alkynyl phenyl ethers (Zhang et al., 2009). Antifungal activity of a lichenicolous fungus against Collectrichum acutatum of hot pepper also established (Wei et al., 2008). One of the researcher, he isolated obligate lichenicolous fungi associated with Parmelia taractica and Peltigera praetextata in Italy and he found that, the clear host specificity of some mycobionts with lichens (Girlanda et al., 1997).

In conclusion, the association of endolichenic fungi was reported in many parts of the world from wide variety of host plants from cryptogams to higher plants. Association of endolichenic fungi is of quite interesting type of host-fungal interactions. As the lichens composed of mutual relationship, these non-obligatory endolichenic fungal presence in lichen thalli attracts further study regarding lichen-fungi inter-relationship and their significance in symbiosis, parasitism or they use lichen thalli as refugia.

\section{Acknowledgements}

The authors would like to thank University Grants Commission, New Delhi, for financial assistance, Chairman, Department of Applied Botany, Kuvempu University for providing the lab facilities. We are thankful to Dr. D.K Upreti and Nayaka S. National Botanical Research Institute (NBRI),
Lucknow, U.P, India for their co-operation during lichen identification and encouragement to carryout the study.

\section{References}

Ahmadjian, V. 1967. The lichen symbiosis. Blaisdell, Waltham, Toronto, London. Pp 152.

Arnold, A.E., Jolanta, M., Lindsay, K.H., Snehal, D.S., Paul, G., Amanda, W., Valerie, H., Frank, K., Lutzoni, F. 2009. A phylogenetic estimation of trophic transition networks for ascomycetous fungi: Are lichens cradles of symbiotrophic fungal diversification? Systematic Biol., 58: 283-297.

Arnold, A.E., Lutzoni, F. 2007. Diversity and host range of foliar fungal endophytes: are tropical leaves biodiversity hotspots. Ecol., 88: 541549.

Arnold, A.E., Maynard, Z., Gilbert, G.S., Coley, P.D., Kursar, T.A. 2000. Are tropical fungal endophytes hyper diverse? Ecol. Lett., 3: 267-274.

Awasthi, D.D. 1988. A key to the macrolichen of India and Nepal. $J$. Hattori Bot. Lab., 65: 207-302.

Culberson, C.F. 1969. Chemical and Botanical guide to lichen products. University of North Carolina Press, Chapel Hill. Pp 628.

Ding, G., Li, Y., Fu, S., Liu, S., Wei, J., Che, Y. 2009. Ambuic acid and Torreyanic acid derivatives from the endolichenic fungus Pestalotiopsis sp. J. Natural Products, 72: 182-186.

Domsch, K.H., Gams, W. 1972. Fungi in Agricultural Soils. London: Longmans Green. Pp 290.

Dreyfuss, M.M.. 1986. Neue Erkenntnisse aus einem pharmakologischen Pilzscreening. Sydowia, 39: 22-36. 
Frankland, J.C. 1974. Decomposition of lower plants. In: Biology of plant litter decomposition. Dickinson, C.H., Pugh, G.J.F. (Ed). Academic press, London. Pp 3-36.

Frohlich, J., Hyde, K.D. 1999. Biodiversity of palm fungi in tropics: are global fungal diversity estimates realistic? Biodiversity and Conservation, 8: 9971004.

Girlanda, M., Isocrono, D., Luppi-Mosca, A.M. 1997. Two folose lichen asmicrofungal ecological niches. Mycologia , 89: 531-536.

Guo, L.D., Huang, G.R., Wang, Y., He, W.H., Zheng, W.H., Hyde, K.D. 2003. Molecular identification of white morphotype strains of endophytic fungi from Pinus tabulaeformis. Mycol. Res., 107: 680-688.

Harutyunyan, S., Muggia, L., Grube, M. 2008. Black fungi in lichens from seasonally arid habitats. Studies in Mycol., 61: 83-90.

Hawksworth, D.L. 1988. The variety of fungal-algal symbioses, their evolutionary significance and the nature of lichens. Botonical J. Linnean Society, 96: 3-20.

Hawksworth, D.L., Hill, D.J. 1984. The lichenforming fungi. Blackie, USA: Chapman and hall, New York. Pp 1157.

He, H., Bigelis, R., Yang, H.Y., Chang, L., Singh, M.P. 2005. Lichenicolins A and $\mathrm{B}$, new bisnaphthopyrones from an unidentified lichenicolous fungus, strain LL-BB0668. Journal of Antibiotics 58: 731-736. Kannangara, B.T.S.D.P., Rajapaksha, R.S.C.G., Paranagama, P.A. 2009. Nature and bioactivities of endolichenic fungi in Pseudocyphellaria sp., Parmotrema sp. and Usnea sp. at Hakgala montane forest in Sri Lanka. Lett. Appl. Microbiol., 48: 203-209.
Krishnamurthy, Y.L., Hemalatha, T.V. 2003. Isolation of Endophytic fungi from some grasses. J. Mycol. Plant Pathol., 33: 305-306.

Krishnamurthy, Y.L., Naik, S.B., Shashikala, J. 2008. Fungal communities in herbaceous medicinal plants from the Malnad region, Southern India. Microbes and Environ., 23: 24-28.

Murali, T.S., Suryanarayanan, T.S., Venkatesan, G. 2007. Fungal endophyte communities in two tropical forests of southern India: diversity and host affiliation, Mycol. Progress, 6: 191199.

Nagamani, A., Kunwar, I.K., Manoharachary, C. 2006. Handbook of Soil Fungi. I.K. International Pvt. Ltd. New Delhi. Pp 1-477.

Petrini, O., Hake, U., Dreyfuss, M.M. 1990. An analysis of fungal communities isolated from fruticose lichens. Mycologia, 82: 444-451.

Pielou, E.C. 1975. Ecological Diversity. John Wiley and Sons Inc. Pp1-75.

Schulz, B., Wanke, U., Draenger, S., Aust, H.J. 1993. Endophytes from herbaceous plant and shrubs: effectiveness of surface sterilization methods. Mycol. Res., 97: 1447-1450.

Strobel, G.A., Long, D.M. 1996. Endophytic microes embody pharmaceutical potantial. American Soc. Microbical News, 64: 263-268.

Suryanarayanan, T.S., Thirunavukkarasu, N., Hariharan, G.N., Balaji, P. 2005. Occurrence of non-obligate inside lichen thalli. Sydowia, 57: 120-130.

U'Ren, J.M., Miadlikowska, J., Lutzoni, F., Arnold, A.E. 2009. Diversity, host specificity and evolution of tropic modes among endophytic, endolichenic and saprotrophic fungi. $C O S, 86-4$. 
Wei, X., Jeon, H.S., Han, K.S., Koh, Y.J., Hur, J.S. 2008. Antifungal activity of lichen-forming fungi against Colletorichum acutatum on hot pepper. Plant Pathol. J., 24: 202-206.

Wen-Chao, L., Zhou, J., Shou, Y.G., Guo, L.D. 2007. Endophytic fungi associated with lichens in Baihua mountain of Beijing,China. Fungal Diversity, 25: 69-80.
White, J.F., Cole, G.T. 1985. Endophytehost association in forage grasses. III. In vitro inhibition of fungi by Acremonium coenophialum. Mycologia, 77: 287-489.

Zhang, F., Liu, Z., Lu, X., Guo, L., Zhang, H., Che, Y. 2009. Allenyl and Alkynyl phenyl ethers from the endolichenic fungus Neurospora terricola. J. Natural Products, 72: 1782-1785.

\section{How to cite this article:}

Vinayaka, K.S., Y.L. Krishnamurthy, Shivakumar Banakar and Prashith Kekuda, T. R. 2016. Association and Variation of Endophytic Fungi among Some Macrolichens in Central Western Ghats, Southern India. Int.J.Curr.Microbiol.App.Sci. 5(6): 115-124.

doi: http://dx.doi.org/10.20546/ijcmas.2016.506.014 